Abundant throughout the country bordering the Upper Missouri.

In the male, the bill is cinnamon colour, darker towards the extremities, the lower mandible lighter. A medial line and a collar passing back of the head and running behind the cheeks, light bluish-grey; a line over the eyes, another running from the lower mandible and the throat, white. Cheeks, rest of the head, and upper parts of the back, dull yellowish-brown streaked with brownish-black. Rump greyish-brown without streaks; two bands of pale yellowish on the wings. The second primary longest. Wings brownish, edged with whitish or pale dull yellow. Tail dull brown, the feathers edged with paler. Sides dull yellowish-brown, the middle of the lower parts much lighter. A small streak of blackish runs from the lower corner of the inferior mandible, legs and feet cinnamon colour.

From point of bill to end of tail $5 \frac{9}{16}$ inches; alar extent $8 \frac{1}{16}$; wing from flexure $2 \frac{7}{16}$; tail $2 \frac{3}{8}$; tarsus nearly $\frac{5}{8}$. Eye brown.

FAMILY XXVI.*-PICINÆ. WOODPECKERS.

GENUS I.†-PICUS, Linn. WOODPECKER.

MISSOURI RED-MOUSTACHED WOODPECKER.

+Picus Ayresit, Aud.

PLATE CCCCLXLIV.-MALE.

This handsome new species was first discovered in the woody borders along the shores of the Upper Missouri, near Fort Union, and both my friends Harris and BeLl procured several specimens, including an adult pair. Mr. BELL also discovered its nest-hole, and on having it cut down, we found six young birds of this species already fledged, and having the red moustache of the old male.

Although this bird is considerably larger than the Picus auratus, so common in our Eastern States, its flight and general habits are much the 


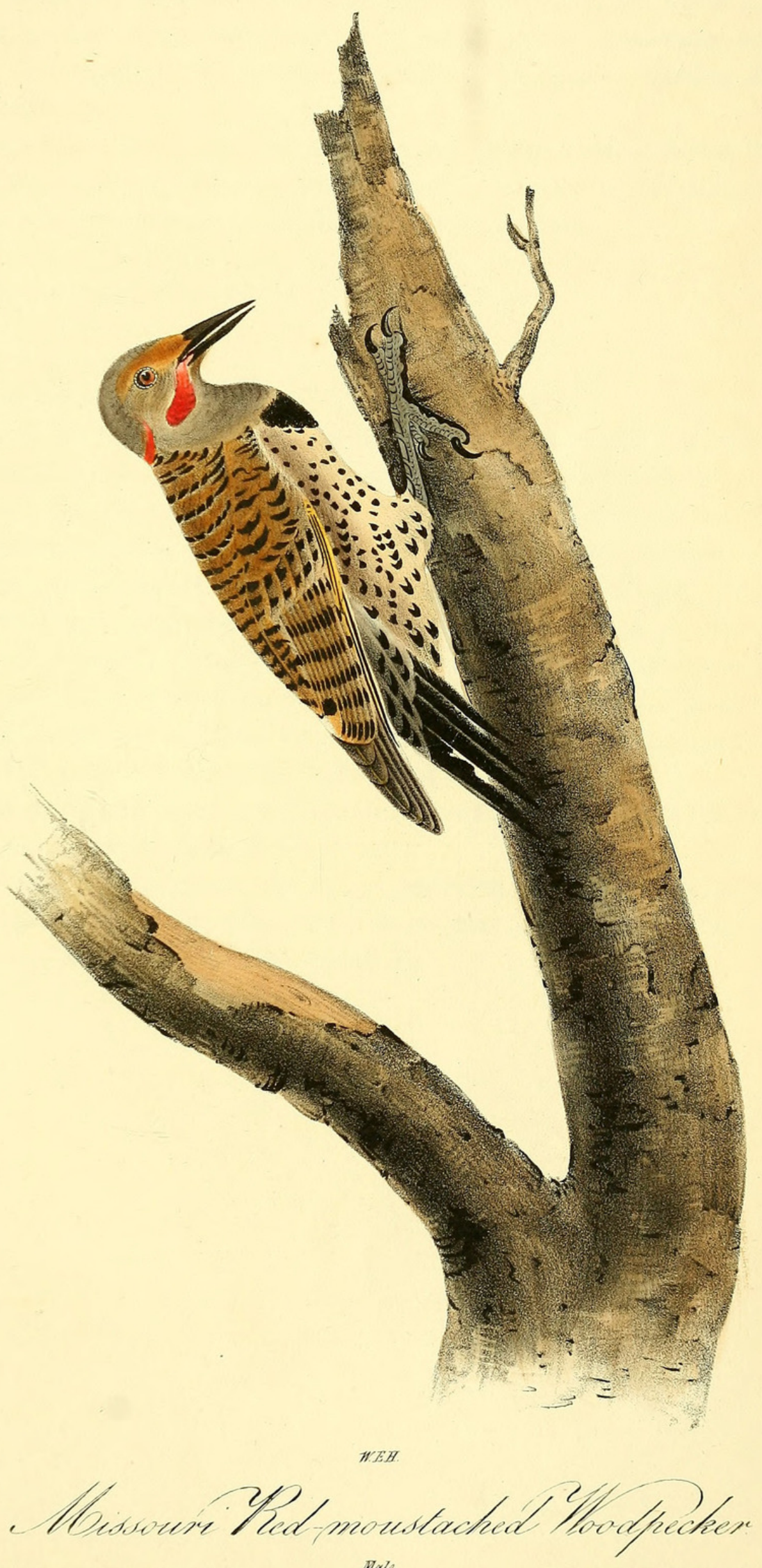


same, but there exists some difference in its notes. The bill is considerably less curved, and the markings, though much like those of the latter, differ in the rounded spots that ornament the lower parts of the body, are much less in size, and incline downward, instead of being placed crossways; and although the third quill is the longest in both, in the present species, the first is much shorter.

I have named this handsome bird after my young and learned friend W. O. Ayres, Esq., who is well known to science as an excellent ichthyologist; and who also is well conversant with the birds of our country.

Missouri Red-moustached Woodpecker, Picus Ayresii, Aud.

\section{$12 \frac{1}{2}, 20$.}

Valleys and ravines of the prairies of the Upper Missouri.

In the Adult Male, the upper part of the head, cheeks, throat downward to near the black patch, of an iron-grey tinged with reddish-buff; lores and around the eye brighter; a transverse very narrow band of carmine on the hind neck; back, scapulars, and secondaries light reddish-brown, tinged with dull green, transversely spotted with black; rump white; tail coverts white, with black markings; primaries and tail feathers blackish-brown, the shafts yellow. A red moustache or streak on each side of the throat from the edge of the lower mandible; lower parts reddish-white, and spotted with black, as well as a large semilunar patch on the fore part of the breast; lower surface of quills and tail feathers yellow, the latter black toward the end.

The female is similar to the male, somewhat smaller, but without the red patch or moustache on the sides of the throat.

Bill to end of tail $12 \frac{7}{16}$ inches; alar extent 20; wing from flexure $6 \frac{7}{16}$; bill along the ridge $1 \frac{1}{4}$, along the edge rather more than $1 \frac{1}{2}$; tarsus $1 \frac{1}{8}$; middle toe 1 , its claw $\frac{1}{2}$; hind toe $\frac{3}{4}$, its claw $\frac{3}{8}$; tail $4 \frac{7}{8}$. 


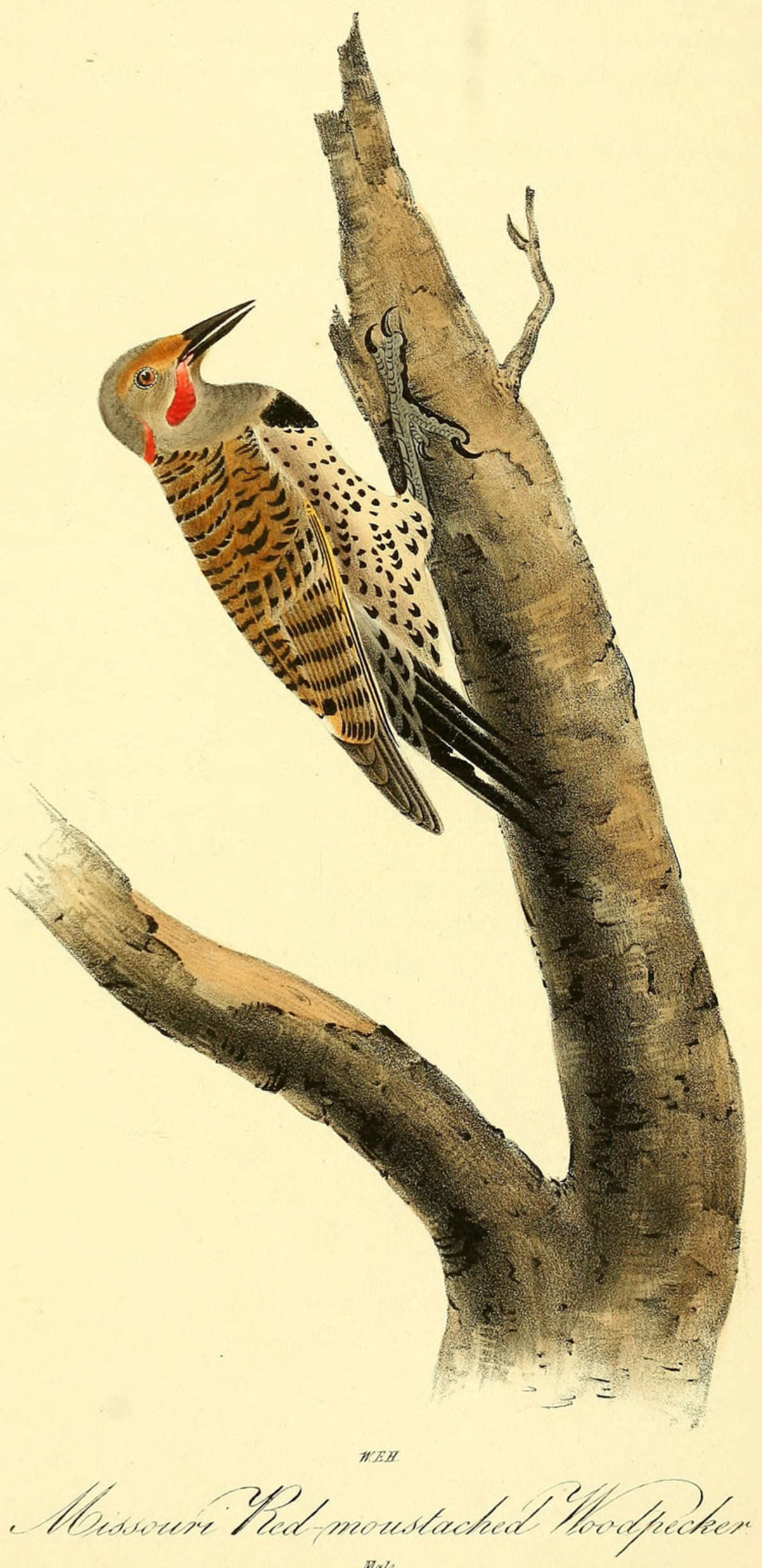




\section{$2 \mathrm{BHL}$ Biodiversity Heritage Library}

Audubon, John James. 1844. "Missouri Red-Moustached Woodpecker, Picus ayresii, Aud. [PI. 494]." The birds of America : from drawings made in the United States and their territories 7, 348-349. https://doi.org/10.5962/p.319611.

View This Item Online: https://www.biodiversitylibrary.org/item/124981

DOI: https://doi.org/10.5962/p.319611

Permalink: https://www.biodiversitylibrary.org/partpdf/319611

\section{Holding Institution}

Smithsonian Libraries

\section{Sponsored by}

Biodiversity Heritage Library

\section{Copyright \& Reuse}

Copyright Status: NOT_IN_COPYRIGHT

This document was created from content at the Biodiversity Heritage Library, the world's largest open access digital library for biodiversity literature and archives. Visit BHL at https://www.biodiversitylibrary.org. 